\title{
PENGEMBANGAN NELAYAN BERBASIS KEARIFAN LOKAL: SEBUAH PENDEKATAN SOCIO-LEGAL ANALYSIS
}

\author{
Ahmad Mony \\ Periset pada Pusat Kajian Kebijakan Hukum (Pusjakum) Setjen DPD RI. \\ Alumnus Magister Sosiologi Pedesaan FEMA-IPB \\ "Email: achmad.mony@gmail.com
}

\begin{abstract}
RINGKASAN
Pengembangan nelayan berakar kuat dari pembentukan regulasi yang menjadi dasar bagi penyusunan kebijakan dan program pembangunan sektoral. Dari pendekatan socio-legal analysis, kritik terhadap peraturan perundang-undangan menjadi bagian dari obyek kajian. Hal ini penting untuk menemukan solusi integratif terhadap pembentukan peraturan yang kurang memihak kepada masyarakat lemah. Selama beberapa dekade, dimensi kearifan lokal hilang dari wajah pembangunan nasional terutama dalam implementasi tata kelola sumberdaya kelautan dan perikanan. Kearifan lokal menemukan ruangnya di era reformasi melalui pembentukan peraturan perundang-undangan dibidang politik dan tata kelola sumberdaya alam, seperti UU Otonomi Daerah, UU Desa, UU Perikanan, UU Pengelolaan Wilayah Pesisir dan Pulau-Pulau Kecil (PWP3K), serta UU Kelautan. Semua undang-undang di atas secara eksplisit mengakui, menghormati dan melindungi kearifan lokal sebagai warisan budaya maritim serta sebagai bagian integral dalam sistem tata kelola sumberdaya. Namun demikian, terdapat beberapa kelemahan dari peraturan di atas, yang secara langsung berdampak terhadap arah dan orientasi pengembangan nelayan berbasis kearifan lokal. DPD RI telah menginisiasi dan mengawal sampai diundangkannya UU No. 7 Tahun 2016 untuk mengisi kelemahan-kelemahan dimaksud dalam upaya pengembangan nelayan, pembudidaya ikan, dan petambak garam. Upaya ini dapat memperkuat strategi pengembangan nelayan berbasis kearifan lokal dalam ruang politik yang kondusif sehingga program pemberdayaan dapat dilakukan secara terpadu, integratif, dan holistik.
\end{abstract}

Kata kunci: desentralisasi, kearifan lokal, nelayan, pemberdayaan

\section{PERNYATAAN KUNCI}

- Pengembangan nelayan melalui penguatan kearifan lokal yang masih hidup di tengah masyarakat merupakan salah satu prasyarat pemberdayaan nelayan karena sistem budaya, ekologi, dan mata pencaharian adalah satu mata rantai kehidupan

- Era reformasi membawa perubahan pada sistem sosial, politik, dan budaya yang banyak memberi ruang besar bagi partisipasi aktif masyarakat di ranah publik, khususnya pada 
sistem tata kelola sumberdaya alam juga sistem tata kelola pemerintahan yang payung hukumnya diadopsi melalui UU No. 23 tahun 2014 tentang pemerintahan daerah serta UU. No.06 Tahun 2014 tentang Desa

- Kearifan Lokal di Indonesia sangat beragam seperti sasi laut di Maluku, panglima laot di Aceh, awig-awig di Lombok, atau Mane'e di Talaud, Sulawesi Utara. Kearifan lokal ini telah manjadi sistem nilai dan budaya yang eksis ditengah masyarakat sebagai bagian dari sistem nafkah, kebudayaan, dan perlindungan lingkungan

- Pembentukan peraturan perundangundanganan terkait dengan perlindungan nelayan, pembudidaya ikan, dan petambak garam yang digagas oleh DPD RI telah membuat terobosan penting dengan mempertimbang-kan kearifan lokal nelayan di masyarakat sebagai bagian dari upaya pemberdayaan dan pengembangan nelayan berbasis kearifan lokal dari hasil riset ini.

\section{REKOMENDASI KEBIJAKAN}

Berdasarkan hasil analisis dari seluruh pembahasan isi kajian, maka terdapat beberapa simpulan yang perlu dipertimbangkan dan diperhatikan dalam upaya pengembangan nelayan berbasis kearifan lokal di Indonesia baik dalam rangka penyusunan peraturan perundang-undang maupun dalam rangka pengambilan kebijakan publik strategis terkait perlindungan dan pengembangan nelayan, yakni:

- Terdapat beberapa kelemahan dalam beberapa peraturan perundang-undangan yang mengatur tentang pemberdayaan nelayan berbasis kearifan lokal. Kelemahan-kelemahan dimaksud perlu disinkronisasi serta dipertegas untuk memberi ruang yang luas bagi pembentukan kebijakan dan program pengembangan nelayan berbasis kearifan lokal.

- Pemberdayaan dan pengembangan nelayan berbasis traditional fishing right (TFR), khususnya nelayan-nelayan tradisional yang memanfaatkan wilayah tangkapan ikan di perairan Australia (Blok 1974) belum sepenuhnya dilindungi dan diberdayakan. Program pengembangan nelayan dengan basis TFR harus diarahkan pada penguatan kapasitas SDM serta fasilitasi teknologi navigasi.

- Hukum adat dan juga kearifan lokal dalam tata kelola sumberdaya pesisir dan laut di Indonesia sudah diakui dan dipertimbangkan dalam rezim tata kelola sumberdaya pesisir dan laut, namun masih lemah dalam revitalisasi, penguatan, dan pengembangannya.

- Kebijakan dan program pengembangan nelayan terlalu diseragamkan untuk seluruh masyarakat pesisir dan pulau-pulau kecil, serta dilakukan secara "spontan" tanpa mempertimbangkan kondisi budaya, sosialekonomi, dan kelembagaan nelayan.

- Regulasi pengembangan nelayan masih bersifat parsial, yang mana lebih difokuskan pada upaya-upaya “intervensi program” seperti fasilitasi bantuan modal, teknologi, akses pasar, maupun pengembangan kapasitas SDM dan kelembagaan. Perlindungan terhadap sistem hukum adat maupun kearifan lokal belum dituangkan secara tegas sebagai dasar bagi pemberdayaan "nelayan tradisional". Akibatnya banyak program pemberdayaan nelayan yang kurang optimal.

\section{PENDAHULUAN}

Kegagalan pembangunan sektor kelautan dan perikanan di masa orde baru diakibatkan oleh 
beberapa hal, diantaranya adalah pembangunan perikanan yang terlalu sentralistik dan tidak memperhatikan kearifan lokal di daerah. Untuk itu, pengelolaan perikanan dan wilayah pesisir harus ditekankan pada dua landasan di atas. Lahirnya Undang-Undang Nomor 32 Tahun 2004 yang diganti dengan Undang-Undang Nomor 23 Tahun 2014 tentang Pemerintahan Daerah telah menegaskan hakekat pengelolaan sistem pemerintahan dari model sentralistik ke desentralisasi yang sebelumnya ditindaklanjuti dengan keluarnya Peraturan Pemerintah Nomor 38 Tahun 2007. Desentralisasi kelautan yang memberi kekuasaan penuh kepada pemerintah daerah ditingkat provinsi untuk melakukan kegiatan-kegiatan di wilayah laut adalah: eksplorasi, eksploitasi, konservasi, adaptasi dan perubahan iklim, pengaturan administratif, pengaturan tata ruang, pengelolaan kekayaan laut, penegakan hukum, dan berpartisipasi dalam pemeliharaan keamanan dan kedaulatan negara ${ }^{1}$.

Secara sektoral, terbitnya UU No. 31 Tahun 2004 yang diubah dengan UU No. 45 Tahun 2009 tentang perikanan telah membuka ruang bagi pelibatan masyarakat adat/lokal dalam mengembangkan kelembagaan lokal untuk pengelolaan perikanan khususnya di wilayah pesisir. Pada poin 2 Pasal 6 telah dijelaskan tentang pengelolaan perikanan untuk kepentingan penangkapan ikan dan pembudidayaan ikan harus mempertimbangkan hukum adat dan/atau kearifan lokal serta memperhatikan peran serta masyarakat. Dalam praktiknya, undang-undang

\footnotetext{
${ }^{1}$ Permendagri Nomor 30 Tahun 2010 Tentang Pedoman Pengelolaan Sumberdaya di Wilayah Laut menyebutkan depinisi wilayah laut sebagai ruang laut yang merupakan kesatuan geografis beserta segenap unsur terkait yang batas dan sistemnya ditentukan berdasarkan aspek administratif dan/atau aspek fungsional yang diukur dari garis pantai ke arah laut lepas dan/atau ke arah perairan kepulauan untuk provinsi paling jauh 12 (dua belas) mil laut dan
}

perikanan lebih berorientasi pada nelayan besar dan kurang adaptif terhadap praktek perikanan tradisional yang dilakukan oleh nelayan kecil ${ }^{2}$. Sebagian besar praktek perikanan tradisional yang diatur dengan kearifan lokal masyarakat, pada dasarnya adalah pengelolaan sumberdaya perikanan yang berada di kawasan pesisir dan wilayah laut yang tidak jauh dari kawasan tersebut. Kekosongan ini selanjutnya ditegaskan dalam UU No. 27 Tahun 2007 yang diubah dengan UU No. 1 Tahun 2014 tentang Pengelolaan Wilayah Pesisir dan Pulau-Pulau Kecil.

Otonomi pemerintahan daerah di bidang politik dan bidang-bidang lainnya termasuk pengelolaan wilayah pesisir diperkuat secara sektoral dengan terbitnya UU Nomor 27 Tahun 2007 yang selanjutnya di perbaharui dengan UU No. 1 Tahun 2014 tentang Pengelolaan Wilayah Pesisir dan Pulau-Pulau Kecil. Kearifan lokal masyarakat dalam bentuk tradisi, pengetahuan maupun kelembagaan lokal yang berhubungan dengan pengelolaan sumberdaya perikanan dan pesisir dihormati dan diakui dalam praktek pengelolaannya. Artinya, kebijakan dan program pemerintah yang bersentuhan dengan wilayah pesisir wajib memperhatikan dan mengakui kelembagaan lokal masyarakat dalam impelementasi program-program pemberdayaan nelayan, konservasi, maupun pengembangan wilayah pesisir dan pulau-pulau kecil. Namun sejauh mana ruang pengakuan negara bagi kearifan lokal tersebut tetap dijalankan oleh masyarakat adat dalam mengelola sumberdaya perikanan?

\footnotetext{
$1 / 3$ (sepertiga) dari wilayah kewenangan provinsi untuk kabupaten/kota termasuk wilayah pesisir dan pulau-pulau kecil.

${ }^{2}$ Pengertian nelayan kecil menurut UU No. 45 Tahun 2009 adalah orang yang mata pencahariannya melakukan penangkapan ikan untuk memenuhi kebutuhan hidup sehari-hari yang menggunakan kapal perikanan berukuran paling besar 5 (lima) gross ton (GT)
} 
Menurut Meinzen-Dick dan Knox (2001) sebagaimana dikutip dalam Kartodihardjo (2013) terdapat dua bentuk devolusi menurut jangkauan kontrol pengguna sumberdaya di tingkat lokal, yakni: (i) apabila kontrol atas sumberdaya ditransfer oleh negara kurang lebih secara keseluruhan, maka ini merupakan kasus devolusi yang mencerminkan bentuk Community-Based Resource Management (CBRM), dan (ii) jika pemerintah masih mempertahankan peran yang besar dalam pengelolaan sumberdaya, namun disertai dengan perluasan peran dari pengguna di tingkat lokal, maka ini kasus devolusi mencerminkan bentuk kolaborasi manajemen atau co-management. Secara regulatif, praktek perikanan tradisional sudah berada pada posisi pengelolaan sumberdaya berbasis masyarakat (Community-Based Resource Management) mengingat begitu luasnya bentuk-bentuk pengakuan pemerintah di ranah sosial, politik, dan budaya dalam implementasi tata kelola pemerintahan dan sumberdaya alam kepada masyarakat lokal.

Mengingat begitu besarnya pengakuan tata kelola pemerintahan ditingkat desa bagi berkembangnya sistem pemerintahan adat serta pengakuan pada sistem tata kelola sumberdaya alam bagi masyarakat adat/tradisional, memunculkan pertanyaan (state of the art): Bagaimana posisi kearifan lokal dalam rezim pengelolaan sumberdaya perikanan bagi pengembangan nelayan tradisional? Untuk itulah diperlukan sebuah studi yang akan menjawab beberapa pertanyaan penelitian mendasar, yakni: (1) Posisi kearifan lokal dalam tata kelola sumberdaya perikanan dan pesisir; (2) Posisi kelembagaan adat dalam tata kelola pemerintahan desa; serta (3) Arah kebijakan pengembangan nelayan berbasis kearifan lokal.

\section{SITUASI TERKINI}

Untuk menelaah lebih mendalam tentang kebijakan pemberdayaan nelayan tradisional melalui pengembangan nelayan berbasis kearifan lokal, perlu untuk melakukan analisis hukum berkaitan dengan rezim perundang-undangan dari masa ke masa yang mengatur tentang kesejahteraan nelayan serta kearifan lokal dalam pengelolaan sumberdaya alam serta sistem pemerintahan adat. Dinamika politik dan perubahan sistem politik memiliki hubungan yang kuat dengan praktikpraktik tata kelola pemerintahan dan tata kelola sumberdaya alam (Ruddle, 1993; Harkes, 1998; Pical, 2012; Mony, 2015). Dalam konteks ini, peran serta masyarakat dalam tata kelola pemerintahan dan tata kelola sumberdaya sangat bergantung pada model sistem politik yang diterapkan. Peraturan perundang-undangan merupakan produk sistem politik yang dapat dijadikan sebagai acuan dalam analisis kebijakan.

Dalam konteks ini, maka perikanan tradisional dan kearifan lokal dalam pengelolaan perikanan termasuk pemanfaatan sumberdaya perikanan menemukan makna pentingnya ditengah kebijakan negara yang makin akomodatif terhadap kelembagaan lokal. Bahkan jika kita set back sesungguhnya muatan-muatan kearifan lokal telah dibahas dan diakui dalam beberapa konvensi internasional, termasuk telah diadopsi dalam beberapa kode etik perikanan. Misalnya, seperti yang telah diatur dalam Konvensi PBB untuk Hukum Laut Internasional Tahun 1982, Kode etik perikanan yang bertanggung jawab tahun 1995 oleh FAO, juga Pedoman Pengamanan Perikanan Skala Kecil Berkelanjutan Tahun 2015 oleh FAO. Konvensi dan kode etik internasional ini telah disetujui oleh negara-negara anggota sehingga memiliki implikasi hukum untuk diadopsi dalam 
sistem hukum nasional (peraturan perundangundangan). Rezim hukum pengembangan nelayan berbasis kearifan lokal disajikan pada Gambar 1.

Konvensi Hukum Laut PBB (UNCLOS) tahun 1982 telah memberikan pengakuan terhadap hak-hak perikanan tradisional (traditional fishing right) negara tetangga yang langsung berdampingan dalam daerah tertentu yang berada dalam perairan kepulauan sebagaimana diatur dalam pasal 51 Unclos. Abiyanda (2013) menyebutkan bahwa, ada beberapa ketentuan yang harus diperhatikan untuk dapat dikategorikan memiliki traditional fishing rights, diantaranya yaitu : (1) Nelayan-nelayan yang bersangkutan secara tradisional telah menangkap ikan di suatu perairan tertentu; (2) Nelayan-nelayan tersebut telah menggunakan alat-alat tertentu secara tradisional; (3) Hasil tangkapan mereka secara tradisional adalah jenis ikan tertentu; dan (4) Nelayan-nelayan yang melakukan penangkapan ikan tersebut haruslah nelayan yang secara tradisional telah melakukan penangkapan ikan di daerah tersebut.

Nelayan Indonesia memiliki hak perikanan tradisional di wilayah perairan Australia (Solihin, 2015), berdasarkan pasal 51 bahwa, sebagai negara kepulauan yang berbatasan dengan negara lain, setiap negara harus mengkui hak perikanan tradisional (traditional fishing rights) suatu negara yang sudah berlangsung lama tanpa mengurangi

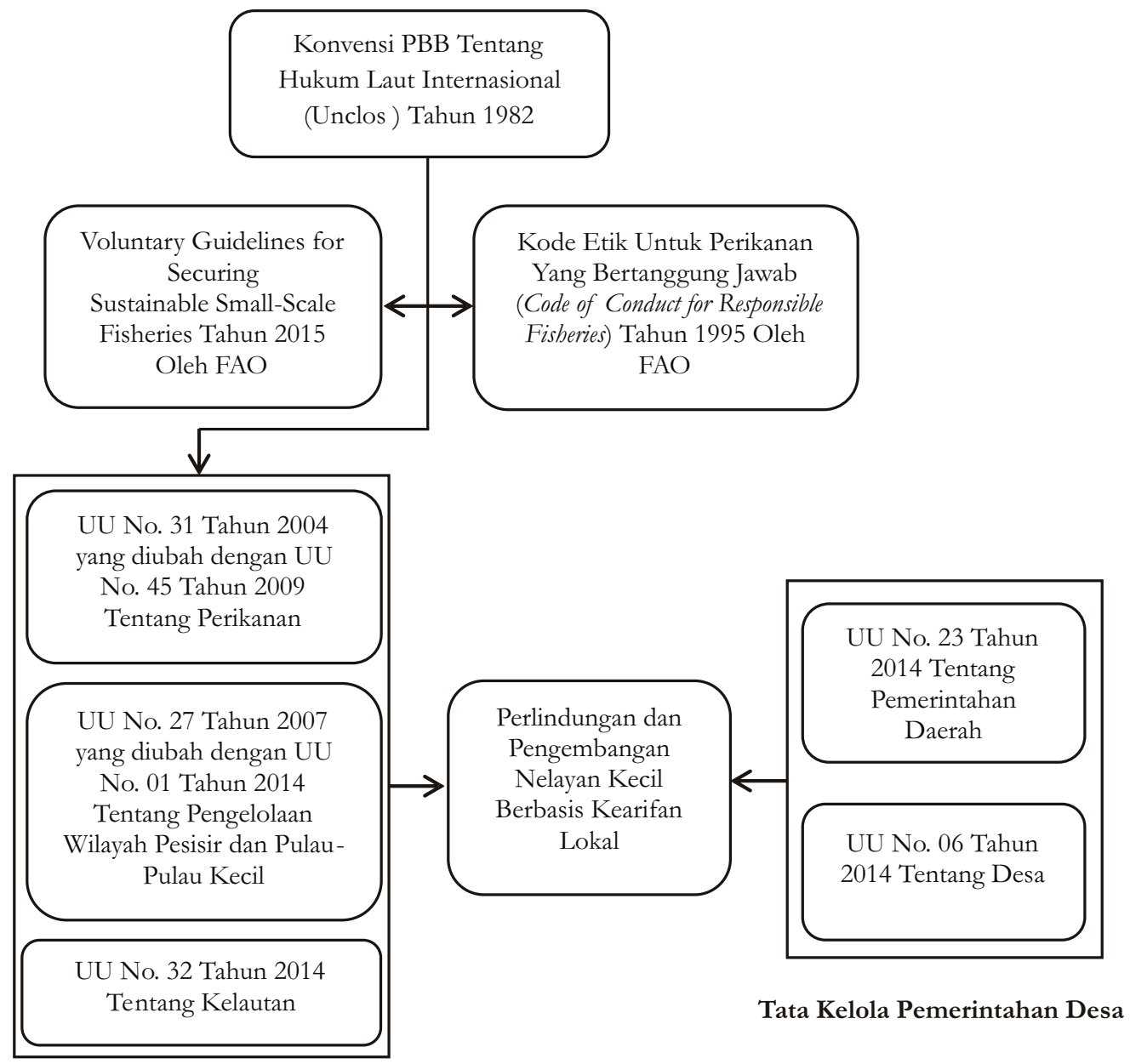

Tata Kelola Sumberdaya

Gambar 1. Rezim hukum pengembangan nelayan berbasis kearifan lokal 


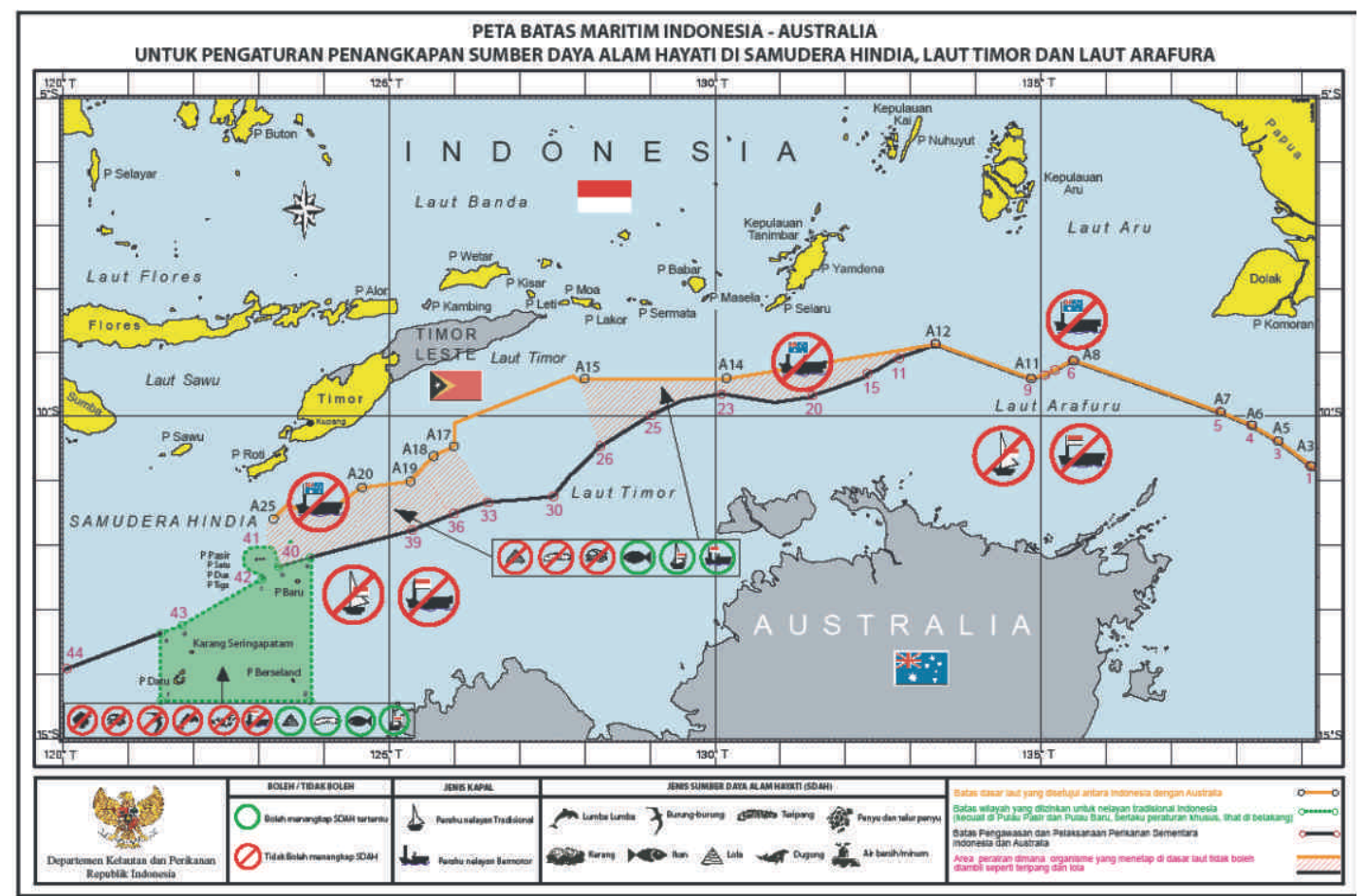

Gambar 2. Peta batas maritim Indonesia dan Australia untuk pengaturan penangkapan sumber daya alam hayati di Samudera Hindia, Laut Timor dan Laut Arafura pada Blok 1974 (Sumber: Solihin, 2015)

arti Pasal 49 tentang status hukum perairan kepulauan. Syarat untuk melaksanakan hak perikanan tradisional adalah perundingan dengan negara-negara tetangga yang bersangkutan. Pada pengaturan hak perikanan tradisional antara Indonesia dengan Australia telah melakukan pertemuan dan menghasilkan tiga buah perjanjian internasional, yaitu Memorandum of Understanding (MOU) 1974, MOU 1981 dan Agreed Minutes 1989. Peta batas maritim Indonesia dan Australia untuk pengaturan penangkapan sumber daya alam hayati di Samudera Hindia, Laut Timor dan Laut Arafura pada Blok 1974 disajikan pada Gambar 2 .

Permasalahan yang ada adalah pemerintah hanya melakukan perlindungan eksternal dengan melakukan MoU dengan pihak Pemerintah Australia. Disisi lain, pemerintah belum optimal melakukan perlindungan internal dengan beberapa cara seperti pengembangan SDM, sosialiasi aturan kepada nelayan tradisional, pengembangan teknologi navigasi, dan kegiatan perlindungan dan pengembangan lainnya. Persoalan nelayan berbasis traditional fishing right harus dilihat berimbang dari dua arah sehingga pemerintah mampu merumuskan solusi penanganan yang berimbang dan adil.

\section{PENDEKATAN DAN METODE KAJIAN}

Karakteristik metode analisis sosio-legal (sociolegal analysis) seperti dijelaskan oleh Bedner et al., (2012) adalah dapat diidentifikasi melalui dua hal berikut ini. Pertama, dalam studi sosio-legal dilakukan studi tekstual, pasal-pasal dalam peraturan perundang-undangan dan kebijakan dapat dianalisis secara kritikal dan dijelaskan makna serta implikasinya terhadap subjek hukum (termasuk kelompok terpinggirkan). Dalam hal ini dapat dijelaskan makna yang terkandung dalam 
pasal-pasal tersebut apakah merugikan atau menguntungkan kelompok masyarat tertentu dan dengan cara bagaimana. Kedua, pada studi sosiolegal telah dikembangkan berbagai metode 'baru'hasil perkawinan antara metode hukum dengan ilmu sosial, seperti penelitian kualitatif sosio-legal (Ziegert, 2005) dan etnografi sosiolegal (Flood, 2005).

Kurniawan (2013) lebih jauh mendeskripsikan bahwa dalam konteks eksistensi sistem hukum adat pada persekutuan masyarakat adat, maka disinilah urgensi akan sebuah kajian hukum yang melampaui tradisi positivism. Merujuk pada kajian sosio-legal, maka di dalamnya terdapat studi antropologi hukum sebagai studi yang sangat berkaitan dengan eksistensi masyarakat tradisional, termasuk masyarakat hukum adat, dan dalam studi antropologi hukum ini terdapat suatu pendekatan yang dikenal dengan istilah pendekatan pluralisme hukum. Secara teknis, kajian ini akan dilakukan dengan teknik: Desk riset, wawancara mendalam, serta Focus Group Discussion (FGD) dengan narasumber-narasumber terpilih. Adapun analisis kajian menggunakan analisis deskriptif komparatif atas semua data yang dikumpulkan. Untuk metode penelitian hukum dilakukan melalui pendekatan yuridis normatif maupun yuridis empiris, dengan menggunakan data-data sekunder maupun data primer.

\section{ANALISIS DAN ALTERNATIF SOLUSI/PENANGANAN}

\section{Periode Pemberdayaan Nelayan Berbasis Kearifan Lokal}

Perkembangan peraturan perundangundangan yang mengatur tentang pengelolaan perikanan dipengaruhi oleh konteks perubahan sistem politik dan ekonomi Indonesia dari masa ke masa. Dalam konteks ini pula, upaya-upaya pemberdayaan nelayan dan pengakuan terhadap hukum adat serta kearifan lokal masyarakat adat/tradisional dalam pengelolaan perikanan dan sumberdaya pesisir mengalami dinamika perubahan. Pada masa orde lama, pemerintah menerbitkan beberapa peraturan perundangundangan yang bertujuan untuk mengembangkan dan memberdayakan usaha nelayan dalam pengelolaan sektor perikanan (baca: perikanan dalam arti luas). Pada Tahun 1957 pemerintah menerbitkan UU No. 18 Tahun 1957 tentang Bank Tani dan Nelayan yang selanjutnya diubah dengan UU No. 77 tahun 1958 dalam rangka memberi akses modal yang luas dan mudah bagi petani dan nelayan dalam mengembangkan usahanya. Selanjutnya, pada tahun 1964 pemerintah juga menerbitkan UU No. 16 Tahun 1964 tentang Bagi Hasil Perikanan dalam rangka melindungi nelayan dan petani ikan (pembudidaya ikan). Namun, pemerintah tidak sedikitpun membahas dan menegaskan tentang muatan hukum adat dan kearifan lokal. Berikut periodisasi perkembangan peraturan Perundang-undangan bidang perikanan disajikan pada Gambar 3 .

Peraturan yang sudah menyinggung secara eksplisit tentang pengakuan terhadap hukum adat dan kearifan lokal masyarakat adalah UndangUndang Pokok Agraria Nomor 5 Tahun 1960. Dalam Undang-undang tersebut mengamanatkan tentang pengakuan terhadap hukum adat (pasal 5) dan hak ulayat masyarakat adat atas tanah adat telah diakui oleh negara (pasal 3). Walaupun undang-undang ini sangat bias agraria, namun dapat digunakan oleh pembudidaya ikan yang mengusahakan kegiatan budidaya ikan di lahan kawasan pesisir dan daratan (perikanan darat) 
dalam menegaskan klaim kepemilikan lahan. Pengakuan atas hak ulayat oleh undang-undang pokok agraria memberikan kepastian hukum atas kepemilikan dan pengelolaan tanah-tanah adat yang dimiliki oleh masyarakat adat terpencil yang umumnya masih terbelakang dan miskin seperti suku Dayak, Papua, Maluku, atau Lombok. Dalam prakteknya, undang-undang ini kurang dijadikan rujukan dalam penyusunan undang-undang sektoral seperti undang-undang kehutanan, perikanan, pertanian, pertambangan, maupun lainnya.

Secara sektoral, pemerintah juga mengeluarkan UU Nomor: 16 Tahun 1964 Tentang Bagi Hasil Perikanan. Proteksi pemerintah terhadap buruh nelayan sangat diperhatikan. Pasal 2 menyebutkan "Usaha perikanan laut maupun darat atas dasar perjanjian bagi-hasil harus diselenggarakan berdasarkan kepentingan bersama dari nelayan pemilik dan nelayan penggarap serta pemilik tambak dan penggarap tambak yang bersangkutan, hingga mereka masing- masing menerima bagian dari hasil usaha itu sesuai dengan jasa yang diberikannya". Untuk meningkatkan kesejahteraan dan kemakmuran rakyat melalui distribusi dan akses permodalan kepada petani, buruh tani dan nelayan untuk berusaha, sebelumnya pemerintah mengeluarkan UU No. 77 Tahun 1958 Penetapan Undang Undang Darurat No. 18 Tahun 1957 Tentang Bank Tani Dan Nelayan sebagai undang-undang.

Pada era orde baru, sistem hukum adat dan kearifan lokal tidak mendapat ruang dalam rezim politik, tata kelola pemerintahan, serta tata kelola sumberdaya alam. Pemerintah orde baru menerapkan sistem pemerintahan sentralistik yang dikendalikan dari pusat (pemerintah pusat) dengan sistem kontrol yang ketat terhadap masyarakat sipil. Dalam rangka menegakkan sistem sentralisasi pemerintahan tersebut, maka pemerintah pusat membuat kebijakan penyeragaman sistem pemerintahan di tingkat desa yang mengadopsi sistem pemerintahan desa model jawa. Penerapan sistem ini secara langsung berperan penting dalam menghancurkan sistemsistem pemerintahan adat serta kelembagaan lokal yang sudah berkembang dan dipraktekkan dalam kehidupan masyarakat adat. Penerapan UU No. 5 Tahun 1979 tentang Pemerintahan Desa menjadi tonggak hancurnya pranata lokal dan kearifan lokal dalam tata kelola pemerintahan adat dan tata kelola sumberdaya alam oleh masyarakat adat/tradisional. Pada Tahun 1979 pemerintah menerbitkan Undang-Undang Nomor 9 Tahun 1985 Tentang Perikanan. Beberapa pasal dalam undang-undang ini telah mengatur tentang pemberdayaan nelayan, namun tetap tidak mengatur tentang hukum adat serta kearifan lokal dalam pengelolaan perikanan. Akan tetapi, menurut Satria (2009a), pada era ini ada Keputusan Menteri Pertanian Nomor 607 Tahun 1976 tentang jalur-jalur penangkapan ikan dimana ada perlinndungan terhadap nelayan dengan kapal dibawah 5 GT dan 10 PK. Namun tujuan mulia ini kurang berhasil karena memang berada dalam desain pengelolaan perikanan yang sentralistik.

Pada era reformasi, terjadi revolusi sistem politik yang berimplikasi pada perubahan terhadap system tata kelola pemerintahan dan tata kelola sumberdaya alam. Hak-hak masyarakat adat/tradisional dalam praktik sistem hukum adat, kearifan lokal, juga pemerintahan adat diberi ruang dalam beberapa peraturan peraundang-undangan. Penulis menyajikan analisis terhadap beberapa peraturan perundang-undangan pasca orde baru yang secara tegas dan eksplisit memberi penghormatan dan pengakuan terhadap hukum adat serta praktik kearifan lokal di masyarakat. 


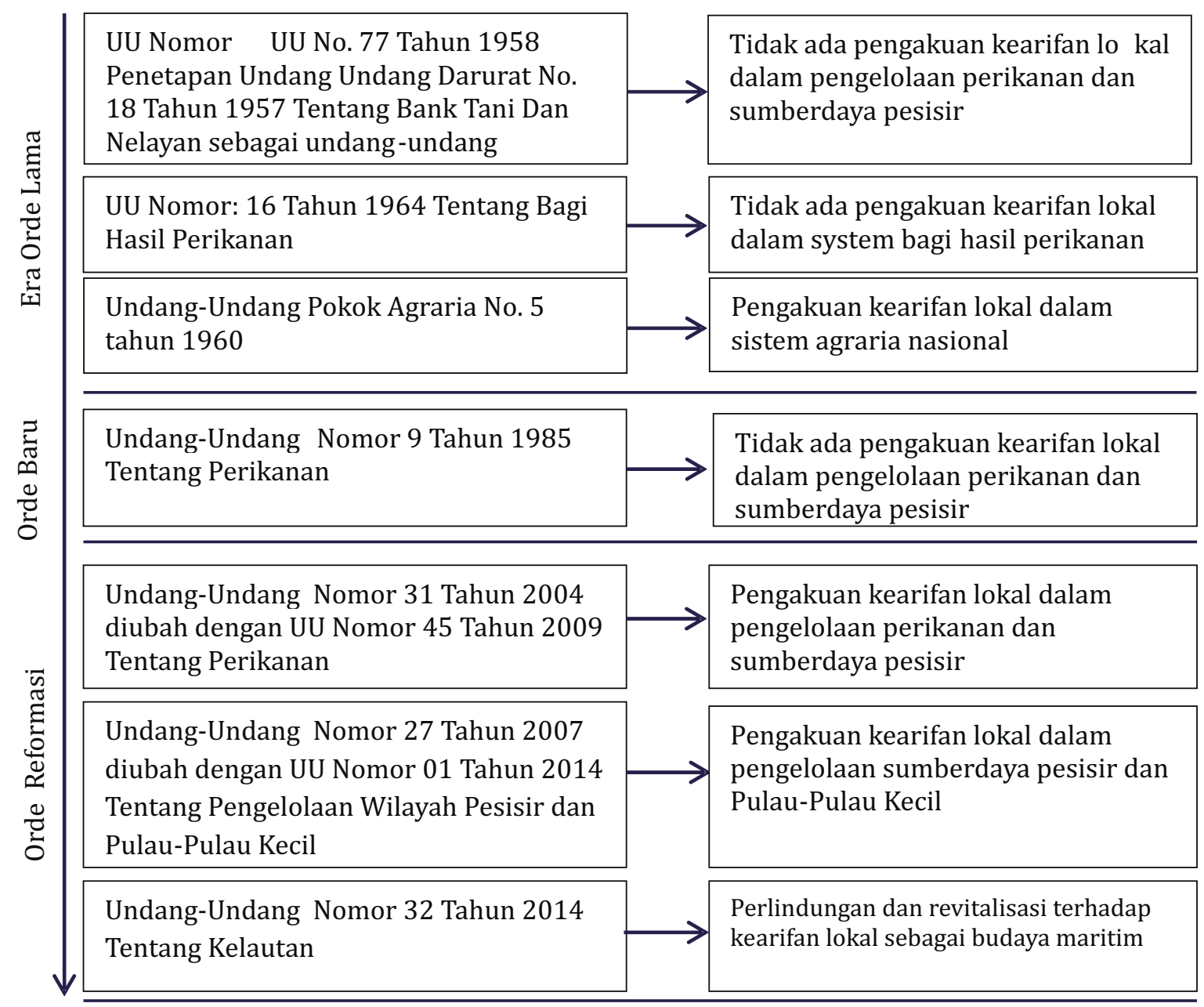

Gambar 3. Periodisasi perkembangan peraturan perundang-undangan bidang perikanan pada masa orde lama, orde baru dan orde reformasi

\section{Nelayan Sebagai Subyek Pemberdayaan}

Sebelum membahas dan menganalisis lebih jauh tentang nelayan dan kearifan lokal, terlebih dulu dilakukan analisis tentang pengertian "nelayan berbasis kearifan lokal" sehingga dapat dijadikan rujukan dalam membatasi obyek pemberdayaan dan pengembangan nelayan berdasarkan kearifan lokal. Dalam UndangUndang No. 27 Tahun 2007 jo UU No. 1 Tahun 2014 tentang Pengelolaan Wilayah Pesisir dan Pulau-Pulau Kecil (PW3PK), terdapat terjemahan yang jelas dan tegas tentang beberapa istilah penting dalam pengelolaan sumberdaya pesisir dan pulau-pulau kecil. Dalam butir 32-35 pasal 1 undang-undang di atas, diterangkan tentang terminologi masyarakat pesisir yang terdiri atas Masyarakat Hukum Adat, Masyarakat Lokal, dan Masyarakat Tradisional yang bermukim di wilayah pesisir dan pulau-pulau kecil.

Penegasan terhadap terminologi-terminologi ini penting kaitannya dengan implementasi strategi-strategi pemberdayaan masyarakat khususnya pengembangan nelayan berbasis kearifan lokal. Atas dasar undang-undang di atas, maka subyek hukum dari praktek pemberdayaan dan pengembangan nelayan berbasis kearifan lokal di Indonesia harus merujuk kepada Masyarakat Hukum Adat serta Masyarakat Tradisional yang memiliki kelembagaan adat serta kearifan lokal (hak tradisional) dalam pengelolaan sumberdaya 
Tabel 1. Penjelasan perbedaan terminologi nelayan, nelayan kecil, dan pembudi daya ikan.

\begin{tabular}{cll}
\hline No & \multicolumn{1}{c}{ Terminologi } & \multicolumn{1}{c}{ Pengertian } \\
\hline 1 & Nelayan & Orang yang mata pencahariannya melakukan penangkapan ikan. \\
\hline 2 & Nelayan Kecil & $\begin{array}{l}\text { Orang yang mata pencahariannya melakukan penangkapan ikan } \\
\text { untuk memenuhi kebutuhan hidup sehari -hari yang menggunakan } \\
\text { kapal perikanan berukuran paling besar 5 (lima) gross ton (GT). }\end{array}$ \\
\hline 3 & Pembudi Daya Ikan & Orang yang mata pencahariannya melakukan pembudidayaan ikan. \\
\hline 4 & Pembudi Daya Ikan Kecil & $\begin{array}{l}\text { Orang yang mata pencahariannya melakukan pembudidayaan ikan } \\
\text { untuk memenuhi kebutuhan hidup sehari-hari. }\end{array}$ \\
\hline
\end{tabular}

Sumber: UU No. 31 Tahun 2004 yang diubah dengan UU No. 45 Tahun 2009

perikanan dan sumberdaya pesisir lainnya. Jika hal ini dikaitkan dengan undang-undang perikanan memang tidak menerjemahkan secara eksplisit tentang terminologi-terminologi lokal/adat seperti yang dijelaskan dalam undang-undang PWK3P di atas. Undang-undang ini hanya memberikan penjelasan tentang pengertian nelayan, nelayan kecil, pembudidaya, serta pembudidaya ikan kecil. Perbedaan antara keempat terminologi ini seperti dijelaskan dalam Tabel 1.

Penggunaan terminologi yang berbeda antar kedua undang-undang ini, setidaknya bisa disinergiskan dengan menggunakan istilah "nelayan tradisional" yang merujuk pada nelayan kecil dengan kapasitas kapal paling besar sebesar 5 GT yang berasal dari komunitas masyarakat hukum adat dan masyarakat tradisional. Harus diakui bahwa kurang tegasnya undang-undang di atas dalam membedakan nelayan dalam arti umum dan nelayan berbasis kearifan lokal menimbulkan penyeragaman dalam kebijakan pengembangan nelayan. Padahal karakterisktik nelayan berbeda berdasarkan kondisi sosial, budaya, dan politik lokal yang mempengaruhinya. Undang-undang perikanan juga tidak secara tegas menjelaskan tentang hak-hak perikanan tradisional (traditional fishing right) sebagai hak pengelolaan perikanan yang sudah dilakukan oleh masyarakat sejak lama.
Karakteristik usaha dan posisi sosial "nelayan tradisional" dalam pengelolaan sumberdaya perikanan maupun pesisir seperti telah dijelaskan dalam bab sebelumnya ditandai dengan berbagai dilema, diantaranya adalah: (1) memiliki status sosial yang rendah dalam sistem sosial karena rendahnya kepemilikan kapital, (2) tersandera dalam beberapa sistem sosial yang "eksploitatif" seperti hubungan patron-klien, (3) tertutupnya akses bagi partisipasi publik dalam perencanaan dan perumusan kebijakan publik, (4) lemahnya kapasitas sumberdaya manusia untuk mengembangkan diri maupun kelompoknya, (5) lemah posisi tawar dalam hubungan relasi kuasa pengelolaan sumberdaya alam dengan berbagai aktor, serta (6) Sistem nafkah masih bercorak subsisten sekedar untuk memenuhi kebutuhan hidup sehari-hari.

\section{Konteks Pemberdayaan Nelayan}

Pengembangan nelayan kecil dan pembudidaya ikan kecil secara eksplisit telah ditegaskan dalam dua rezim undang-undang yakni undang-undang perikanan dan undang-undang PW3PK. Dalam pasal 60 UU No. 31 Tahun 2004 jo UU No. 45 Tahun 2009 dijelaskan tentang upaya pemberdayaan nelayan kecil dan pembudidaya ikan kecil dilakukan dengan tiga skema utama 
yakni pengembangan akses modal yang mudah, pengembangan kapasitas sumberdaya manusia, serta pengembangan kapasitas kelembagaan. Untuk keperluan pemberdayaan di atas, pasal 62 dan 63 menegaskan lebih jelas tentang strategi pemberdayaan melalui (i) penyediaan sumber pembiayaan bagi upaya pemberdayaan nelayan kecil dan pembudidaya ikan kecil diusahakan dari berbagai sumber dalam negeri maupun luar negeri dan (2) Pengusaha perikanan mendorong kemitraan usaha yang saling menguntungkan dengan kelompok nelayan kecil atau pembudi daya ikan kecil dalam kegiatan usaha perikanan. Secara regulatif, undang-undang ini sudah menegaskan tentang upaya pemberdayaan nelayan kecil dan pembudidaya ikan kecil secara jelas, detail, dan holistic. Namun, kelemahan undangundang ini adalah belum memisahkan dengan tegas bagi upaya pemberdayaan nelayan kecil dan pembudidaya ikan kecil dengan pendekatan hukum adat dan kearifan lokal masyarakat adat/tradisional. Uraian lengkap tentang hal ini seperti disajikan pada Gambar 4 berikut.

Kebijakan pengembangan nelayan kecil dan pembudidaya ikan kecil selanjutnya dijelaskan secara rinci melalui Peraturan Pemerintah Nomor 50 Tahun 2015 Tentang Pemberdayaan Nelayan Kecil dan Pembudidaya Ikan Kecil. Konteks pemberdayaan nelayan dalam undang-undang perikanan di atas ternyata berlaku umum untuk seluruh komunitas nelayan dan pembudidaya ikan kecil. Artinya bahwa nelayan kecil dalam komunitas-komunitas hukum adat/masyarakat tradisional dianggap memiliki persoalan kesejahteraan yang sama dengan komunitas nelayan kecil lainnya. Disinilah letak kelemahan konsep pemberdayaan nelayan kecil dalam rezim pengelolaan sumberdaya ikan.

Regulasi yang mengatur tentang pengelolaan perikanan sumberdaya pesisir, serta pemberdayaan nelayan, disisi lain, pasti memiliki berbagai kelemahan. Kelemahan tersebut dapat ditinjau dari berbagai sudut pandang. Secara umum terdapat beberapa kelemahan dalam

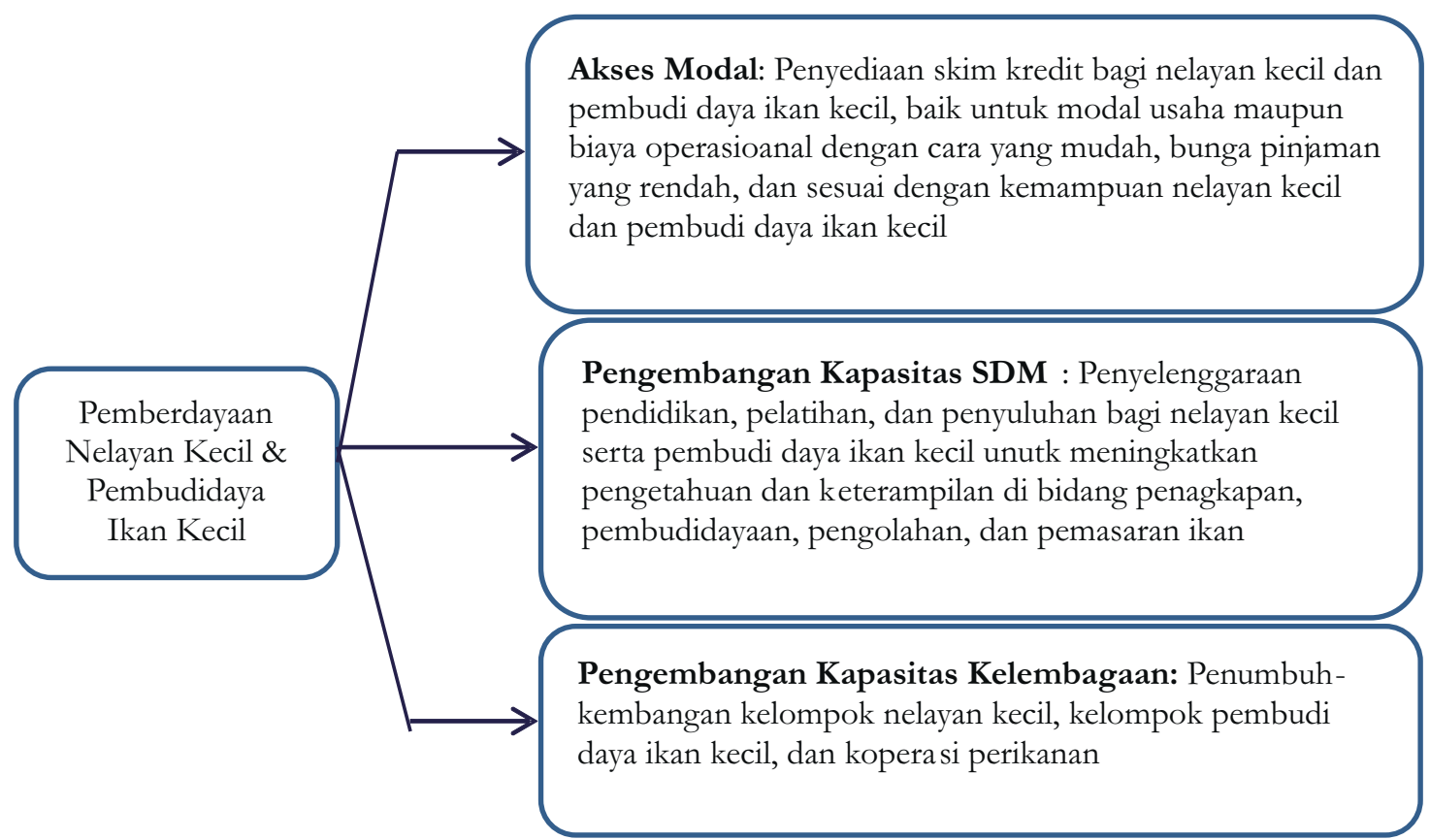

Gambar 4. Skema pemberdayaan nelayan kecil dan pembudidaya ikan kecil sesuai amanat UndangUndang Perikanan 
pengembangan nelayan berbasis kearifan lokal sebagaimana telah dianalisis sebelumnya terhadap dua rezim undang-undang di atas. Pertama, perlu adanya sinkronisasi dan penegasan tentang kedudukan kearifan lokal dalam pengelolaan sumberdaya pesisir dan perikanan. Perbandingan kepentingan dan orientasi dari tiga UndangUndang sektoral tentang kearifan lokal disajikan pada Gambar 5.

Undang-undang perikanan hanya memberi arahan pertimbangan agar hukum-hukum adat atau kearifan lokal masyarakat dipertimbangkan dalam kebijakan pengelolaan perikanan. Regulasi ini masih sangat lemah mengatur tentang pengakuan terhadap hukum adat dan kearifan lokal masyarakat dalam pengelolaan sumberdaya perikanan. Regulasi tersebut juga lemah dalam melindungi nelayan dan pembudidaya ikan kecil yang dilakukan oleh komunitas-komunitas adat di wilayah pesisir dan pulau-pulau kecil karena regulasi ini tidak diperkuat melalui regulasi turunan seperti sebuah Peraturan Pemerintah tentang Rencana Pengelolaan Perikanan Berbasis Hukum Adat/Kearifan Lokal.

Undang-undang Pengelolaan Wilayah Pesisir dan Pulau-Pulau Kecil telah bergerak lebih maju dari pada undang- undang perikanan. Masyarakat adat juga masyarakat trasidional telah disebutkan dan diakui secara eksplisit. Demikian juga dengan pengakuan terhadap hak-hak masyarakat adat, masyarakat tradisional serta kearifan lokal dalam pemanfaatan sumberdaya di wilayah pesisir dan pulau-pulau kecil. Kelemahan undang-undang ini sama seperti undang-undang perikanan yang tidak memberi ruang terbitnya Peraturan Pemerintah sebagai peraturan turunan yang merinci lebih mendalam tentang perlindungan hak-hak masyarakat adat/tradisonal dalam rencana pengelolaan wilayah pesisir dan pulau-pulau kecil. Sementara Undang-Undang Kelautan telah mengamanatkan tentang penjelasan rinci atas peran masyarakat dalam pembangunan kelautan melalui revitalisasi hukum adat dan kearifan lokal di bidang kelautan.

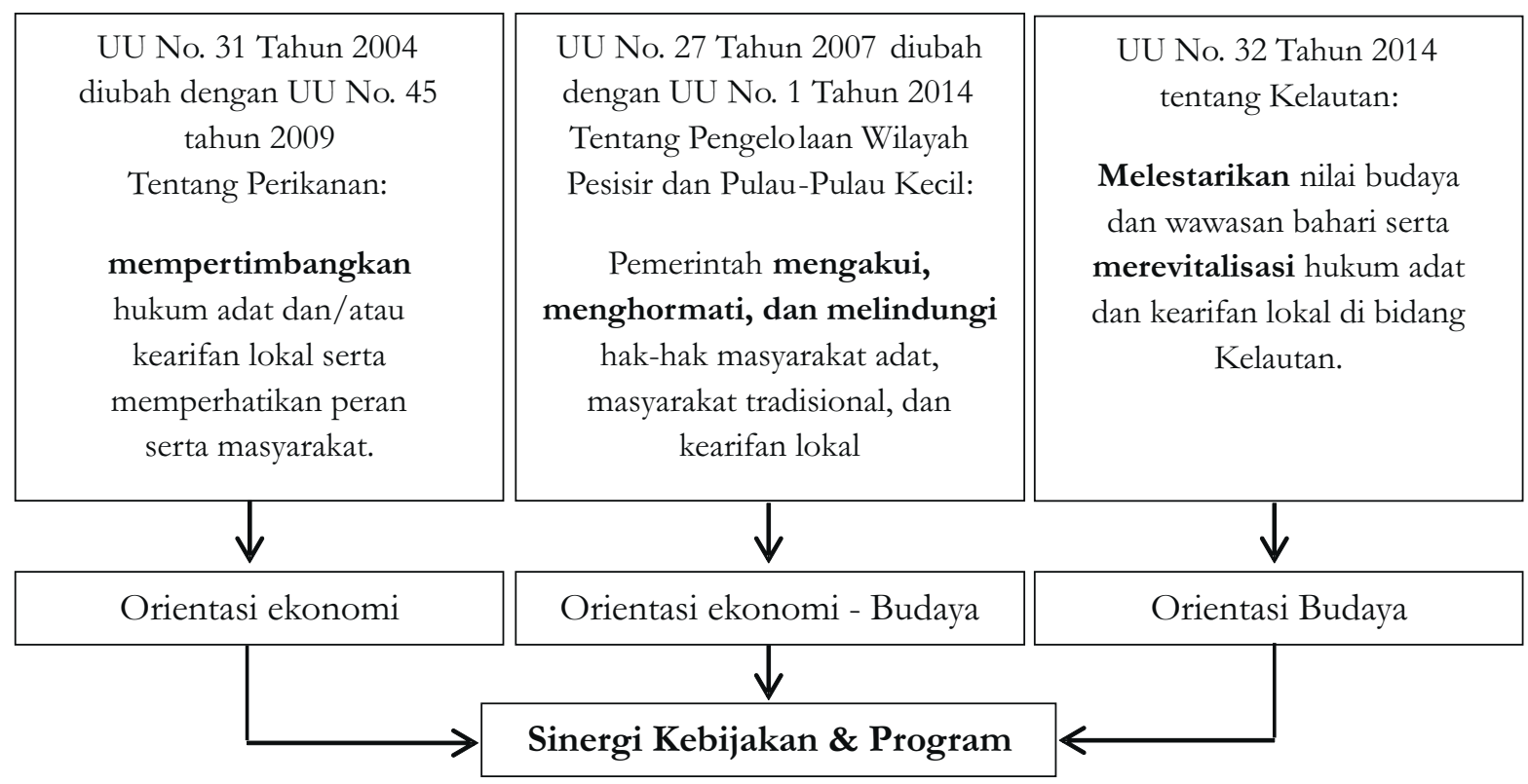

Gambar 5. Perbandingan kepentingan dan orientasi dari tiga Undang-Undang sektoral tentang kearifan lokal 
Perbedaan penggunaan terminologi tentang upaya "pengembangan" kearifan lokal dalam pengelolaan perikanan, sumberdaya pesisir dan pulau-pulau kecil serta pembangunan kelautan menjadi awal dari kelemahan perumusan strategi pengembangan nelayan berbasis kearifan lokal karena ketiga undang-undang bisa ditafsirkan berbeda oleh para pengambil kebijakan.

\section{Strategi Pengembangan Nelayan}

Perumusan strategi pengembangan nelayan terutama nelayan berbasis kearifan lokal harus di dasarkan pada tantangan dan permasalahan yang dihadapi oleh para nelayan yang merupakan komunitas masyarakat pesisir dengan perangkat hukum adat serta kearifan lokal yang dimilikinya. Dari pendekatan socio-legal analysis, permasalahan yang dihadapi dalam pengembangan nelayan berbasis kearifan lokal seperti dirinci dalam Gambar 6.

1) Pengembangan Nelayan Berbasis Traditional Fishing Right.

Salah satu wacana penting yang kurang mendapat perhatian adalah perlindungan terhadap keberadaan nelayan tradisional yang memanfaatkan hak pemanfaatan sumberdaya perikanan di kawasan perairan negara lain berdasarkan hak tradisional (Traditional Fishing Right) yang melekat pada aktifitas perikanan mereka. Nelayan-nelayan tradisional Indonesia yang sering berkunjung ke wilayah perairan Australia, khususnya Pulau Pasir (Ashmore Reef) berasal dari daerah Pulau Rote, Flores, Buton, Sabu, Timor, Alor, Sulawesi dan Maluku (YPTB, 2005 dalam Solihin, 2011). Dengan demikian, adanya kebiasaan yang dilakukan oleh nelayan-nelayan tradisional Indonesia sejak berabad-abad yang lalu ini merupakan peluang yang besar bagi terjadinya konflik antara Indonesia dan Australia, sebagai negara-negara yang masing-masing memiliki kedaulatan (Solihin, 2011). Meskipun telah dilakukan penandatanganan perjanjian yang mengakui hak atas nelayan tradisional Indonesia, dalam pelaksanaannya di lapangan aparat Pemerintah Australia seringkali melakukan tindakan kekerasan terhadap nelayan-nelayan Indonesia. Kompleksitas permasalahan nelayan tradisional Indonesia di wilayah perikanan Australia telah berlangsung sejak tahun 1980-an (Stacey, 2007 dalam Solihin, 2015). Tindakan kekerasan tersebut mencuat pada tahun 2005, yaitu pada tragedi "Clean Water Operation" yang dilakukan oleh aparat Pemerintah Australia.

Dalam hal penanganan dan pengembangan nelayan tradisional berbasis Traditional Fishing Right (TFR) penanganannya agak berbeda dengan strategi pengembangan nelayan secara umum, termasuk nelayan dengan basis kearifan lokal, misalnya: (1) Penguatan kapasitas SDM untuk memahami norma-norma perjanjian bilateral, serta syarat-syarat praktek TFR di perairan Australia, (2) Penguatan pemanfaatan teknologi navigasi bagi kapal nelayan. Teknologi navigasi hanya digunakan untuk memastikan lokasi penangkapan agar nelayan tidak keluar dari wilayah TFR, (3) Diseminasi informasi tentang pedoman pemanfaatan sumberdaya perikanan di wilayah negara lain (Australia), serta (4) Pendampingan dan konsultasi hukum terhadap nelayan yang tertangkap.

2) Strategi Pengembangan Nelayan Berbasis Kearifan Lokal

Beberapa riset telah dilakukan dalam rangka perlindungan dan pengembangan nelayan berbasis kearifan lokal atau sering dirujuk dengan istilah nelayan tradisional. Menurut Sulaiman et al., 


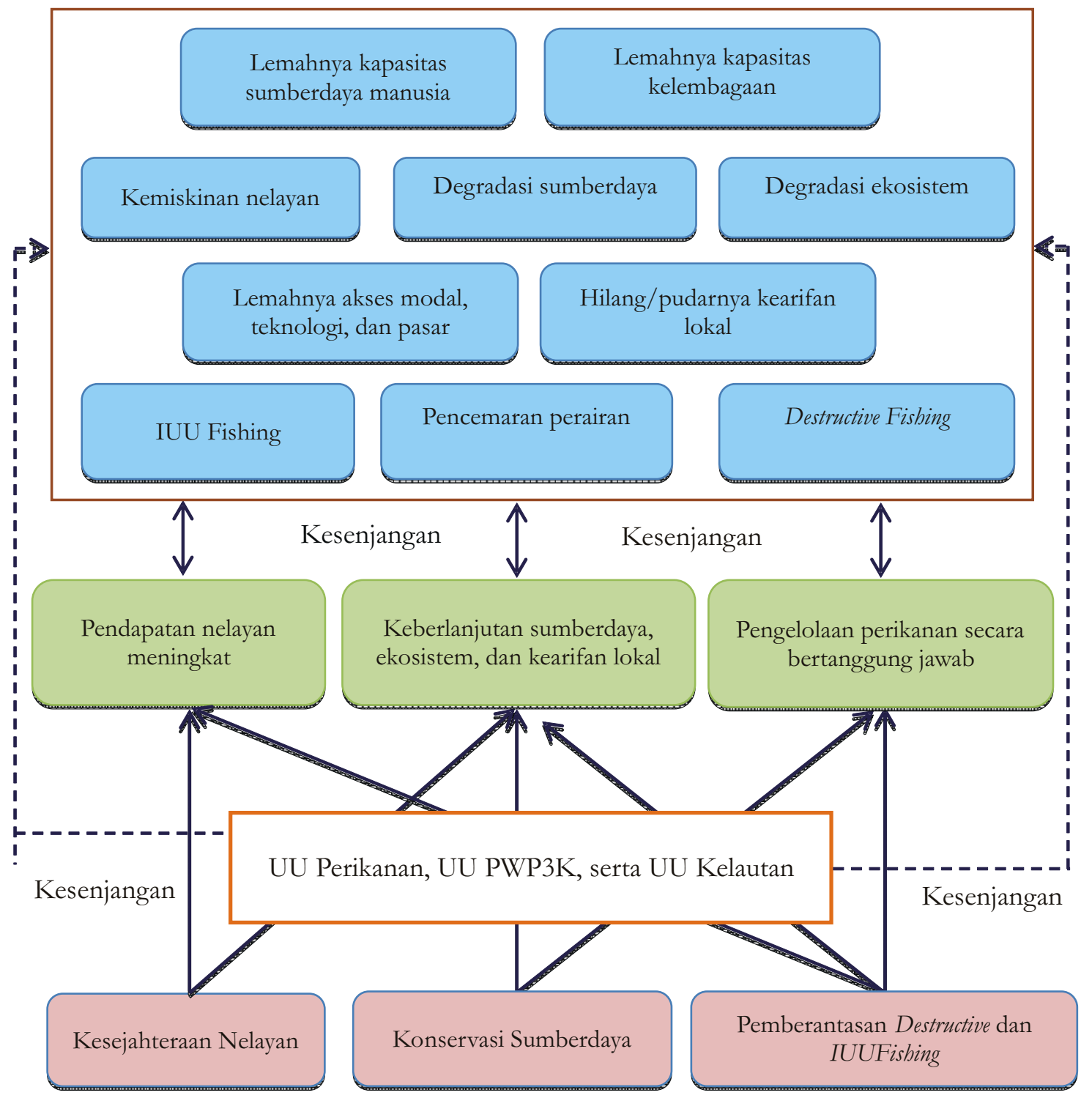

Gambar 6. Komparasi kebijakan pemberdayaan nelayan, kondisi aktual, serta peraturan perundangundangnya

(2015), berdasarkan hasil kajian tentang "Pembangunan Hukum Perlindungan Nelayan Tradisional di Aceh dalam Kaitan Pemanfaatan Sumber Daya Perikanan secara Berkeadilan" disampaikan bahwa: Pertama, perlindungan nelayan tradisional sangat penting dilakukan oleh negara dalam pemanfaatan sumber daya perikanan disebabkan karena keberadaan nelayan tradisional dalam memanfaatkan sumber daya perikanan tidak semata-mata sebagai kegiatan ekonomi survival semata. Kegiatan pemanfaatan sumber daya perikanan oleh nelayan tradisional juga terkait dengan kebudayaan, dalam kaitan hubungan manusia dengan lingkungan, hubungan sesama manusia, bahkan dengan Pencipta. Dengan kondisi demikian, maka perlindungan nelayan tradisional baik untuk kemandirian maupun kapasitas mereka, tidak bisa dilepaskan dari subsidi dan pengawasan zona mereka. Kedua, faktor keadilan dalam perlindungan nelayan tradisional harus didalami mengingat beberapa hal, yakni angka kemiskinan, akses pemanfaatan, 
kemudahan mengakses pasar, dan akses pengelolaan. Semua hal itu harus mendapat perhatian mengingat tanpa pemihakan kepada nelayan tradisional dan berpotensi hancurnya lingkungan fisik yang berujung pada lingkungan sosial budaya dan ekonominya. Nelayan tradisional menganggap bahwa semua ekosistem dalam sumber daya pasarnya saling terkait satu sama lain. Ketika terganggu satu subsistem, maka akan mengganggu lainnya. Ketiga, pembangunan hukum perlindungan nelayan harus terkait dengan isu dasar yang paling penting, yakni menghadirkan negara dalam memberikan pelayanan hak dasar sebagaimana disebutkan dalam Konstitusi. Pembatasan akses atau tidak adanya pemihakan pada dasarnya akan menggiring nelayan tradisional dalam kondisi marjinal baik secara politik, sosial, budaya, maupun ekonomi.

Satria (2007) menegaskan bahwa strategi mata pencaharian yang dapat dilakukan untuk memutus rantai persoalan nelayan, meliputi: (i) Pengembangan strategi nafkah ganda. Bagi nelayan kecil, strategi ini untuk mempertahankan batas subsistensinya atau bertahan hidup. Penguatan dan pengembangan strategi nafkah ganda bagi nelayan kecil dapat dilakukan dengan dua pendekatan, yakni pengembangan sarana dan alat penangkapan ikan, serta pengemabngan kegiatan alternatif seperti budidaya ikan, pengolahan ikan tradisional, serta mata pencaharian alternatif lainnya, (ii) Strategi pemodalan. Strategi ini diperlukan untuk memperkuat pengembangan strategi nafkah ganda di atas. Kegiatan penangkapan penuh dengan ketidakpastian sehingga posisi tawar kadang lemah dalam mengakses modal pada lembaga keuangan formal. Untuk itu, pemerintah perlu mengembangkan akses modal, seperti LKM Nelayan yang mudah di akses, dan (iii) Strategi Makro. Strategi ini menjadi pondasi dari pelaksanaan dua strategi sebelumnya. Strategi ini menekankan sejauh mana sektor perikanan dan kelautan mendapat tempat dalam kebijakan strategis nasional.

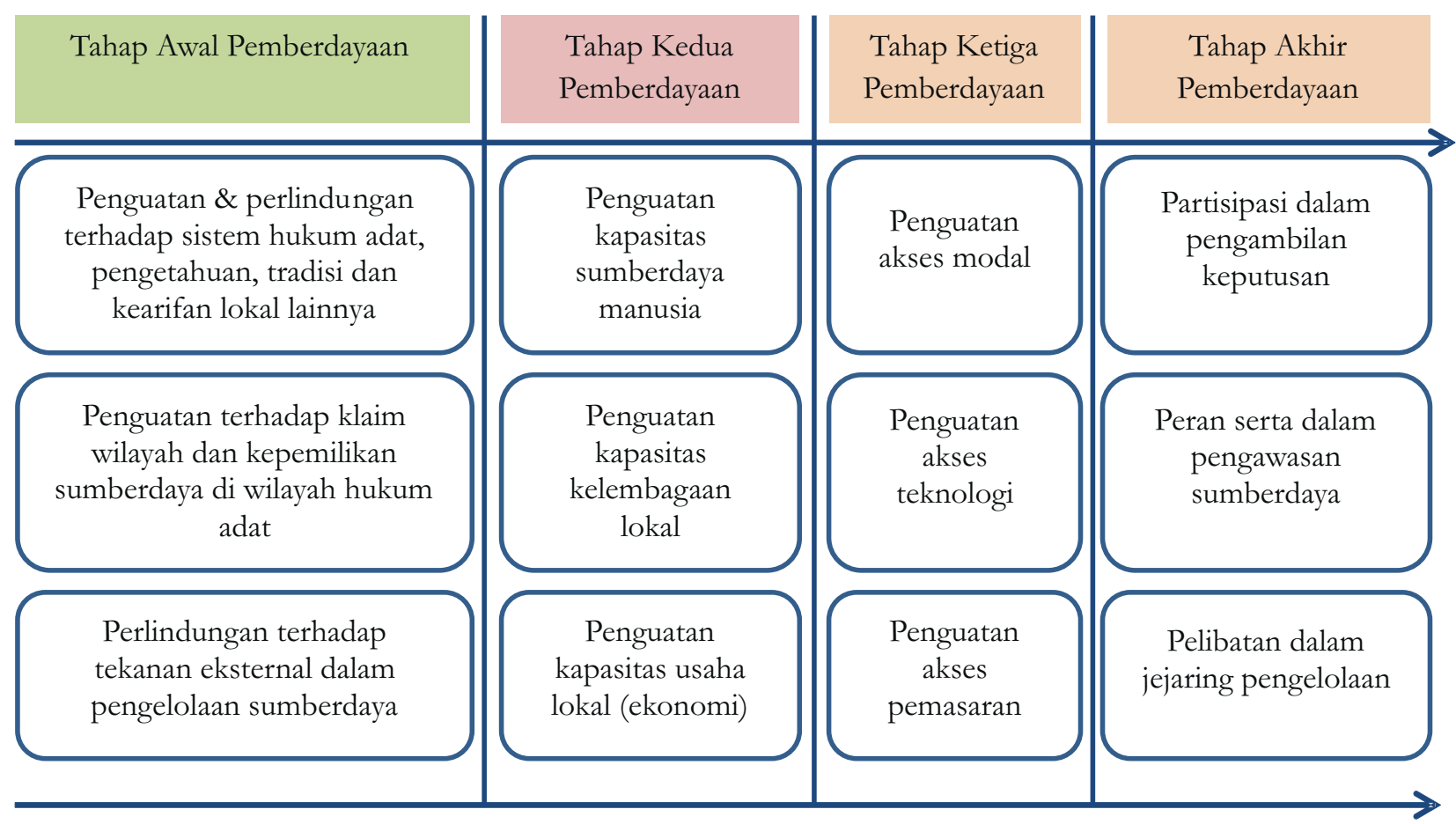

Gambar 7. Tahapan pengembangan nelayan kecil berbasis kearifan lokal 
Strategi lainnya adalah pengembangan nelayan berbasis kearifan lokal seharusnya dilakukan secara bertahap menurut evolusi atau tingkat adaptasi masyarakat adat terhadap transformasi sosial baik ditingkat internal maupun eksternal. Tahapan pengembangan nelayan kecil berbasis kearifan lokal disajikan pada Gambar 7. Loncatan dalam strategi pengembangan nelayan pada komunitas hukum adat atau masyarakat tradisional hanya akan menimbulkan masalah lain akibat tidak sinergisnya strategi pemberdayaan dengan tingkat adaptasi masyarakat terhadap strategi yang diterapkan. Dalam beberapa kasus pemberdayaan nelayan kecil pada komunitas hukum adat atau komunitas tradisional, strategi perlindungan terhadap sistem sosial, sistem hukum adat, klaim wilayah, dan klaim terhadap sumberdaya alam yang ada didalamnya justru merupakan strategi utama melindungi sistem nafkah (ekonomi sub-sistem) pada masyarakat. Pada tahap awal, upaya perlindungan terhadap sistem sosial (hukum adat atau kearifan lokal) merupakan kebijakan mendasar dalam memberdayakan masyarakat adat. Sebab, kehancuran sistem sosial, sumberdaya, serta klaim wilayah merupakan awal dari kehancuran sistem nafkah masyarakat adat. Dengan demikian, strategi pengembangan nelayan berbasis kearifan lokal harus dilakukan secara gradual mengikuti tingkat adaptasi masyarakat terhadap intervensi program pemberdayaan dari pihak luar.

\section{REFERENSI}

Abiyanda, B. 2013. Upaya Pemerintah Indonesia Dalam Membela Hak Nelayan Tradisional Di Pulau Pasir Australia. eJournal Ilmu Hubungan Internasional. Edisi 2013, 1 (2): 523-530. Univ. Mulawarman.
Bedner, W.A., Irianto, S., Otto JA., Wirastri TD. 2012. Kajian Sosio-Legal. Pustaka Larasan. Bali

Harkes, I. 1998. An Institutional Analysis Of Sasi Laut, A Fisheries Management System In Indonesia. Proceedings of the International Workshop on Fisheries Co-management.

Kartodihardjo. 2013. Kembali ke Jalan Lurus. Kritik Penggunaan Ilmu dan Praktek Kehutanan Indonesia. Forci Development. Bogor

Mony, A. 2015a. Ekologi Politik Pengelolaan Sumberdaya Pesisir. Studi Kasus Pengelolaan sasi Laut di Maluku. Tesis. IPB. Bogor.

Ruddle, K. 1993. External Forces and Change in Traditional Community-Based Fishery Management Systems in the Asia-Pacific Region. The Journal of Maritime Anthropological Studies Vol. 6, No. 112.

Satria, A. 2007. Sawen: institution, lokal knowledge and myths in fisheries management in North Lombok, Indonesia. In N. Haggan, B. Neis, \& I. G. Baird (Eds.), Fishers' knowledge in fisheries science and fisheries management (pp. 199-220). Paris: UNESCO.

Satria, A. 2009a. Ekologi Politik Nelayan. LKIS.Yogyakarta. Indonesia

Solihin, A. 2011. Naskah Review Laporan Kemajuan Kajian Socio-Legal Analysis Pengembangan Nelayan Berbasis Kearifan Lokal. Bogor

Solihin, A. 2015. Hak Ekonomi Nelayan Tradisional Indonesia Di Wilayah Perbatasan. Jurnal Pustaka HPI. diakses tanggal 13 November 2015 : http:// pustakahpi.kemlu.go.id/app/ Volume\%203,\%20 S e ptemberDesember\%202011_9_17.PDF. 
Sulaiman, Mansur, M.T., Zulfan., Abdullah, M.A. 2015. Pembangunan Hukum Perlindungan Nelayan Tradisional di Aceh dalam KaitanPemanfaatan Sumber Daya Perikanan secara Berkeadilan. Seminar
Nasional "Peluang dan Tantangan Menghadapi Masyarakat Ekonomi Asean, Perspektif Hukum dan Perlindungan Sumber Daya Laut", Fakultas Hukum Universitas Muhammadyah. Yogyakarta 